\title{
FORM AND TRANSLATION OF INDONESIAN WORD WITH ATTACHED CONFIX
}

\author{
I Gusti Ayu Mita Cestalia Putri \\ Fakultas Ilmu Budaya Universitas Udayana \\ mitacestalia@gmail.com
}

\begin{abstract}
Abstrak
Penelitian ini menguji perubahan kata dengan imbuhan konfiks dari Indonesia ke Inggris. Sumber data dari penelitian ini adalah novel Indonesia berjudul "Mirah dari Banda". Buku ini diterjemahkan ke Bahasa Inggris dan dipublikasikan sebagai "Mirah of Banda". Kata dengan imbuhan konfiks dan terjemahannya kemudian melalui proses penelitian dalam mengumpulkan data. Data dianalisa dengan strategi deskriptif kualitatif. Teori yang digunakan untuk mencari bentuk kata adalah teori morfologi sementara teori yang digunakan untuk mencari terjemahan adalah teori prosedur penerjemahan. Hasil penelitian menunjukan kemampuan menerjemahkan kata berimbuhan konfiks ke Bahasa Inggris melalui proses infleksional dan derivasional. Adanya pergeseran kelas kata yang mengganti bentuk kata benda dan kata kerja. Prosedur penerjemahan yang digunakan adalah transposisi, terjemahan literal dan modulasi.
\end{abstract}

Kata Kunci: confix,morphology, translation, word

\section{Introduction}

In the modern era, translation has an important role in human activities. Multiple fields such as linguistic, technology, sociology, law, science, medic, and others need a translation. Its importance becomes a part of the media. Many news, movies, and stories were translated into different languages.

According to the book Introducing Translation Study, translation was derived from the Latin word translatio means transporting (Robinson, 997b:15). During the process of translation, the source text (ST) in the source language (SL) changes the target text (TT) into the target language (TL). Translation reproduces the closest equal meaning from SL to TL (Nida: 1969).

The differences in language bring matters in translation. In the relationship of word structure, there are two main problems. Those are grammatical class word and morphological categories related to the various classes. In a grammatical class word, there are changes from the noun to the verb when describing an event. Depends on the language syntactical rule, a shift around noun and pronoun occurs when defining the participants. Few hurdles mark the morphological categories like; 1) aspect, 2) tenses, 3) inclusive and exclusive first-person plural, 4) dead and alive marker, and 5) honorifics (Nida, 1982:116).

This distinction leads to structural differences in morphological form. Morphology consists of several components. One of these word units is called affix. Affix is attached to a word to create new meaning. A prefix is attached at the beginning of the word while suffix is attached at the end of the word. There is also a term called confix. It is a prefix and suffix attached at the same time. This prefix and suffix must not be separated since they will create different meanings or make no sense at all. This confix exists in Indonesian language. The examples of the words 
are perkotaan (cities), kesabaran (patience), pembekuan (freezing), bermalaman (overnight), etc. This confix adds function to its root word. The word kebesaran (too big) comes from the word besar (big). Confixke-...-an in that word has a component meaning related to size.

English does not have a confix.The difference of inner word structure is a problem in translation Therefore, a word with confix is translated grammatically, depends on the word and the structure of the sentence. Because of the gap between two languages, the process of translation has become a challenge. Therefore, linguists create procedures, strategies, and methods for translation. In 1950, two French scholars examined the linguistic aspect of translation. They were Jean-Paul Vinay and Jean Darbelnet. While others compared two languages to have a better understanding of it, Vinay and Darbelnet focus on the process of translation. This work later produced Stylistique comparée du français et de l'anglais: méthode de traduction which is translated into English as Comparative Stylistics of French and English: a Methodology for Translation.

After learning about the translated word form, it is possible to research the type of translation. There are two methods of translating, direct literal translation and oblique translation. The literal translation is a word per word translation which rely on a structural sentence while the oblique translation is a procedure used when a conceptual element or the structure of SL cannot be translated without disrupting grammar or stylistic in TL.

There are a few corresponding studies related to this journal. The research called "meN-kan/me-I Verbs in Indonesian and Their Translation into English with Special Reference to Handbook of Indonesian Foresty: by Bentang (2009) found out about the equivalence of morphological verbs from Indonesian to English. $\mathrm{He}$ focused on verbs with prefix and suffix meN-...-kan and me-...-I. Utami (2013) in her study "The Indonesian Base and Affixes Verb Forms and Their Translational Equivalence in English with Reference to Edensor" analysed the translation of base verb and word with the attached prefix, suffix and confix. The used suffixes are $d i$, $d i-\ldots-i, d i-\ldots-k a n, t e r-$ and $k e-\ldots-a n$. The verb base form and verb with the attached suffix were translated based on the English morphological verb form: the base, the $-s$ form (person singular present, the past, the -ing participle and the -ed participle. The used translation technique theory was Molina and Albir (2002). The result showed how Indonesian verb forms had various translations. Prefix ter-was translated into base form, past form, progressive, past progressive, past participle, past progressive participle, and past perfect participle. From the eighteen translation technique, only four are used in the research. Those are adaptation, description, modulation, and transposition.

The journal discovers the form then the translation procedure. It is interesting to find the equal word with the attached confix from Indonesian into English. The example the word kebanjiran (flood) is a noun. It comes from root word banjir(flooded) which is a verb. Confixke-...-an gives meaning suffered to the base word. It changes the word class and the translation. Because English does not have confix, the translation follows the grammar structure. There are possibilities to know a correlation between the two languages. 


\section{Material and Method}

This study used descriptive qualitative research. The source text is an Indonesian novel Mirah dari Banda by Hanna Rambe. This book later translated by Toni Pollard and published in English. The research was examined by comparing SL in Indonesian and TL in English.

Morphology is the study of word formation and its relationship with other words. It analysed unit of words such as lexemes, morpheme, root, base, stem, affix. A lexeme is a common word of abstract vocabulary with specific meaning and sound. It can be attached with morpheme to create a new word or meaning. A morpheme is the smallest unit of a word. There are two types of morpheme, free morpheme, and bound morpheme. A free morpheme can stand on its own while bound morpheme needs to be attached to other words to create meaning. The example is $-e r$ in the word player or $-s$ in tables (Chaer, 2008:21).

Chaer (2008:21) explained that root is the core of word without nothing attached like a chair, run, big, cake, talk, sad, etc. A base is a unit that can be attached. The stem is a part of a word that exists before any inflectional affix such as a player in players or work in working. Affix is morpheme which only occurs when attached to others to create a new word or word form. Affix is divided into three parts: prefix, infix, and suffix. A prefix is an affix put at the beginning of the word, the example un- in untie. An infix is an affix put in the middle of the word. The example in Tagalog is bato (stone) attached with infix -in-turns into binato (stoned). A suffix is an affix put at the end of the word, the example is -less in fearless.

Other then those three, there is confix. Confix is a part of affix which consists of two-element as a basic form to make a new class word (Putrayasa, 2008:31). The prefix or suffix in confix cannot stand alone. They must be attached simultaneously or the word would have a different meaning or do not make sense. An example in Indonesian is the word perguruan (institution). It came from the word guru (teacher) with confix per-...-an. The word perguru or guruan does not exist.

There are six confixes in Indonesian: ber-...-an, ke-...-an, per-...-an, peN-...an, per-kan, and per-i. However, the data is divided into four parts which are ber-...an, ke-...-an, peN-...-an, and per-...-an. Per-kan and per-i have limited word, therefore will not be used. Each of these confixes has its meaning when attached to a root word. The word class of the word can change or remains the same after putting a confix. The example the word bakar (burn) is a verb. After being attached with confix $k e-. . . a n$ with the component meaning affected or suffered, it becomes kebakaran (on fire) which is a noun.

The form analysed with grammatical theory by Carstairs - Mc Carthy (1988). The data is categorized based on the inflectional process and derivational process. Inflectional carries the grammar and does not change the meaning. There are three inflectional forms:

1. The noun form consists of singular or plural.

2. The verb form consists of the present participle, past participle, progressive participle, perfect or passive participle.

3. The adjective form consists of base form or comparison or superlative. 
The derivational process changes the word class and its meaning. In some cases, the word class remains the same but it has a different meaning from the previous word. The word with derivational morpheme will be divided based on its root, suffix, infix, or affix.

The word kedinginan (Adj) comes from the root dingin(Adj) with the attached confixke-...-an. It is translated into cold (Adj). It can be concluded that the process used in that translation is inflectional because there is no attachment in the translated word. In contrast, a word with an attached confix with a derivational process can be found with a different word. The word $\operatorname{percakapan}(\mathrm{N})$ comes from the word cakap $(\mathrm{N})$ with the attached confixber-...-an. It is translated into conversation $(\mathrm{N})$ from the word converse $(\mathrm{V})$ with the attached suffix $-(t($ ion $))$. It can be concluded that it is a derivational process from the attachment of suffix.

After the form is examined, the translation word is analysed. Vinay and Darbelnet (1995) mentioned seven translation procedures.

1. Borrowing is the concept of taking a foreign term in SL into TL. The example is the word hamburger.

2. Calque is using the foreign term in SL then translates it in TL and create a new expression. There are two types of calque which are lexical calque and structural calque. Lexical calque complies with the structure of TL. The example is Valentine's day in English is translated into hari Valentine in Indonesian. Structural calque complies with the structure of SL. The example tea bag in English is translated into teh celup in Indonesian.

3. The literal translation is translating words from ST to TT word per word. This concept acceptable if the same syntax, meaning, and style from SL are transferred in TL.

4. Transposition is replacing a word class in the structure of the grammar while keeping the meaning. The example buruh pelabuhan (high) changes into porter (low). Another example is kaca pembesar and magnifying glasses. The bold words have different word classes. Magnifying is a verb while pembesar is a noun.

5. Modulation is one way to retain the message by changing in point of view. The example:Indonesian: "Mat sedang berdebat dengan Pak Camat, mungkin membicarakan kontrak pembelian pala atau pencarian minyak," jawab Wendy tersenyum. (page 63)

English: She looked up to see Matt still talking to the camat and smiled. "Maybe they're discussing buying a nutmeg plantation or prospecting for oil." (page 28)

The sentence "Mat sedang berdebat dengan Pak Camat"in the sentence is direct speech. However, in English, it is translated into Matt still talking to the camat which is indirect speech.

6. Equivalence is the process of transferring an expression in SL with another equivalence word that exists in TL. The example the English's idiom "Don't cry over spill milk" has a similar message with Indonesian idiom "Nasi telah menjadi bubur".

7. Adaptation is replacing the word in SL with different translations to make things suitable in TL because the word is considered taboo or a cultural 
difference between the two languages. The example the word football in England is translated into soccer in the USA.

\section{Results and Discussion \\ Word with confix ber-...-an \\ Data 1}

SL: Ada kuli kontrak asal Jawa, ada romusha (kuli kerja paksa gratis di zaman penjajahan Jepang) yang berserakan di berbagai tempat di Indonesia. (page 20)

TL: There had been indentured coolies from Java and romusha slave laborers during the Japanese occupation who'd been scattered all over Indonesia. (page 11)

The word berserakan (V) has a root word serak (V) with confix ber-...-an. The component meaning of confix ber-...-an in the sentence means plurality and irregularity.The meaning of berserakan is a mess; in ruin; located irregularly. It was translated into had been scattered $(\mathrm{V})$. The meaning of scattered is occurring or found at intervals or various locations rather than all together. This is a part of the inflectional process as a verb. The word derivedconfixchanges intopassive participle form with $b e+-e d$.The used translation procedure istransposition because the expression berserakan can be translated literally in SL through the grammatical structure with uncommon equivalence in TL(Newmark, 1988).

\section{Data 2}

SL: Sudah terlalu sering rumah roboh tertimpa batu yang berterbangan, tertimbun abu, pantai yang longsor dan benda di atasnya turut terjun ke laut. (page 114)

TL: All too frequently houses were destroyed by flying rocks and buried under ash and there were landslides along the coast. (page 53)

The word berterbangan (V) has a root word terbang (V) with confix ber-...an. The component meaning of confix ber-...-an in the sentence means plurality and irregularity. The meaning of berterbangan is flying everywhere; spatter or float in the air. It was translated into flying (Adj). The meaning of flying is moving rapidly, especially through the air. This is a part of the inflectional process as an adjective. The word comes from root fly (V) with morpheme -ing. This is a transposition translation procedure because there is a word class shift during translation (Vinay and Darbelnet, 1989). The words berterbangan (V) turns into flying (Adj).

\section{Data 3}

SL: Rombonganinimasukkeluar kampong bergantian. (page 222)

TL: The group wove in and out of one village after another (page 116)

The word bergantian (V) has a root word ganti (V) with confixber-...-an. The component meaning of confixber-...-an in the sentence means reciprocal action. The meaning of bergantianis change with each other; take turns; exchange; interchangeably. It was translated into wove (V). The meaning of wove is make (a complex story or pattern) from a number of interconnected elements. This is a part of the inflectional process as an irregularpast verb. One lexeme may be represented by two (or more) quite distinct root morpheme. Using suppletion, it can be concluded that the transformation happens in roots not affix (Carstair and McCarthy, 1988:33). The used translation procedure is modulation. A word, phrase, or other linguistic units are created because there is no equivalence in TL (Vinay and Darbelnet, 1989). The word bergantian is not equal with wove. Therefore, there is an addition phrase after another in the target language. 


\section{Data 4}

SL: Saya gembira kalau banyak tamu berdatangan dari Jawa. (page 305)

TL: I enjoy it when visitors come from Java. (page 160)

The word berdatangan (V) has a root word datang (V) with confixber-...-an. The component meaning of confixber-...-an in the sentence means plurality and irregularity. The meaning of berdatangan is coming in-crowd. It was translated into come (V). The meaning of come is moving or traveling into a place. This is a part of the inflectional process as a present verb without any attachment. The used translation procedure is literal translation because the word in SL is translated literally in TL (Vinay and Darbelnet, 1989).

\section{Word with confix ke-...-an}

\section{Data 1}

SL: Orang inilah yang sekarang akan menjadi tuan rumahnya berlibur di sebuah tempat terpencil di Indonesia, kepulauan Banda. (page 7)

TL: It was he who would now be a host of their holiday in the remote archipelago of Banda. (page 7)

The word kepulauan $(\mathrm{N})$ has a root pulau $(\mathrm{N})$ with confix ke-...-an. The component meaning of confix $k e-\ldots-a n$ in the sentence means area. The meaning of kepulauan is a cluster of few islands. It was translated into archipelago $(\mathrm{N})$. The meaning of archipelago is an extensive group of islands. This is the inflectional process as a singular noun without morpheme.The used translation procedure is literal translation because the word is translated directly (Vinay and Darbelnet, 1989).

\section{Data 2}

SL: Itulah salah satu keuntungan terbang dalam pesawat kecil. (page 15)

TL: This was one of the advantages of flying in a small plane. (page 9)

The word keuntungan $(\mathrm{N})$ has a root untung $(\mathrm{N})$ with confix ke-...-an. The component meaning of confix ke-...-an in the sentence refers to the base or topic itself. The meaning of keuntungan is profit; benefit. It was translated into advantages $(\mathrm{N})$. The meaning of advantage is a favorable or desire feature. This is the inflectional process as a plural noun because the word is attached with morpheme $-s$. The used translation procedure is transposition because the singular noun in SL turned plural in TL (Newmark, 1988).

\section{Data 3}

SL: Setelah kemerdekaan, orang kaya meninggalkan tanah Banda. (page 25)

TL: After independence the wealthy residence had departed Banda. (page 16)

The word kemerdekaan $(\mathrm{N})$ has a root word merdeka (Adj) with confix ke-...$a n$. The component meaning of confix $k e-\ldots-a n$ is related to the degree or level. The meaning of kemerdekaan is the state of independent, free, is not colonized. It was translated into independence $(\mathrm{N})$. The meaning of independence is the fact or state of being independent. This is a derivational process because of the attachment of affixes.The word independence comes from word root dependent (Adj) with attached derivational prefix in- means negated $\mathrm{X}$ becomes independent (Adj). However, after attached by the derivational suffix -ence means activity or result of $\mathrm{X}$, the word independent changes into independence $(\mathrm{N})$. The used translation procedure is the 
literal translation because the sentence is translated word per word and can be reversed(Vinay and Darbelnet, 1989).

\section{Data 4}

SL: Seluruh rambutnya telah berwana putih kekuningan, namun rambutnya masih tebal. Mungkin juga amat panjang karena sanggulnya tampak besar dan berat. (page 64)

TL: Her hair was yellowish-white, yet still thick in its heavy bun and probably quite long. (page 29)

The word kekuningan (Adj) has a root kuning (Adj) with confix ke-...-an. The component meaning of confix $k e-. . .-a n$ in the sentence is expressing a resemble like color X. The meaning of kekuningan is slightly yellow; mixed with the color yellow. It was translated into yellowish (Adj). The meaning of yellowish is having a yellow tinge; slightly yellow.This is a derivational process because of the attachment of affixes. The word comes from the word yellow (Adj) with the suffix -ish means somewhat or rather $\mathrm{X}$. The used translation procedure is modulation because the aims of the sentence is to find natural equivalence and clarify meaning in TL (Vinay and Darbelnet, 1989).

\section{Word with confix peN-...-an}

\section{Data 1}

SL: "Ke sini ada penerbangan komersial seminggu dua kali." (page 25)

TL: "Two commercial flights land here every week." (page 13)

The word penerbangan $(\mathrm{N})$ has a root word terbang $(\mathrm{V})$ with confix peN-...an. The component meaning of confix $p e N-\ldots$-an refers to the process. The meaning of penerbangan is traveling by plane. It was translated into flights $(\mathrm{N})$. The meaning of flight is an act of flying; a journey made through the air or in space, especially in a timetabled journey made by the airline.This is the inflectional process as a plural noun because the word is attached with morpheme $-s$. The used translation procedure is modulation. In SL the word with the attached confix is a part of the object noun but it is part of subject in TL.There is a change in subject point of view (Vinay and Darbelnet, 1989). This also transposition translation procedure because the word penerbangan is a singular noun, but it turns into plural in flights(Newmark, 1988).

\section{Data 2}

SL: Hanya beberapa ratus meter dari rumah putih sudah pelabuhan. (page 27)

TL: The harbour, lined with several old, semi-ruined warehouse, was a few hundred meters from the White House (page 16)

The word pelabuhan $(\mathrm{N})$ has a root labuh (Adj) with confix peN-...-an. The component meaning of confix peN-...-an refers to a place. The meaning of pelabuhan is the place to anchor the ship. It was translated into the harbour $(\mathrm{N})$. The meaning of harbor is a place on the coast where ships may moor in the shelter.This is the inflectional process as a singular noun without morpheme.The used translation procedure is modulation because of a change point of view(Vinay and Darbelnet, 1989). The word pelabuhan in SL is the object of a passive sentence while in TL harbour is subject in the active sentence.

\section{Data 3}


SL: Di bagian belakang rumah yang indah-indah itu dibuatkan pengasapan dan pengeringan pala. (page 111)

TL: Behind these beautiful houses the sheds for curing and drying nutmeg were built. (page 52)

The word pengasapan $(\mathrm{N})$ has a root word asap $(\mathrm{N})$ with confix peN-...-an. The component meaning of confix $p e N-\ldots$-an refers to the process. The meaning of pengasapan is a process, method of bloating. It was translated into curing $(\mathrm{N})$ from word root cure $(\mathrm{V})$. The meaning of cure is preserving meat, fish, tobacco, or animal skin by salting, drying, or smoking.This is a part of the inflectional process as a progressive participle verb with morpheme -ing. The used translation procedure is transposition. The word pengasapan is translated into gerund, which is a shift because the difference in grammatical structure. (Newmark, 1988).

\section{Data 4}

SL: $\quad$ Sudahtentupengumumaninimengejutkansekaligusmenjengkelkan para perkenier. (page 116)

TL: Naturally the announcement shocked and angered the perkenier. (page 54)

The word pengumuman $(\mathrm{N})$ has a root umum (V) with confix peN-...-an. The component meaning of confix $p e N-\ldots$-an in the sentence is related to process. The meaning of pengumumanis process, a way, act of announce. It was translated into announcement $(\mathrm{N})$. The meaning of announcement is a formal statement about a fact, occurrence, or intention. This is a derivational process because of the attachment of affixes. The word comes from the word announce (V) with the suffix -ment means activity or result of $\mathrm{X}$. The used translation procedure is literal translation because the word is translated directly(Vinay and Darbelnet, 1989).

\section{Word with confix per-...-an}

\section{Data 1}

SL: Pesawat itu dicarter dari perusahaan swasta yang berpusat di Bandung. (page 6)

TL: The plane had been chartered by a private company in Bandung. (page 7)

The word perusahaan $(\mathrm{N})$ has a root usaha $(\mathrm{N})$ with confix per-...-an. The component meaning of confix per-...-an in refers to the base or topic itself. The meaning of perusahaan is an incorporated organization that handled transactions or business. It was translated into a company $(\mathrm{N})$. The meaning of the company is the commercial business. This is the inflectional process as a singular noun without morpheme. The used translation procedure is transposition because the word perusahaan swasta is modifier-modified in ST but changes into a private company which is modified-modifier (Newmark, 1988).

\section{Data 2}

SL: Di dalam pengembaraannya di berbagai tempat di dunia bersama suaminya, pertanyaan di atas terus bergema di sudut hatinya. (page 20)

TL: In her travels across much of the word with her husband, these were the questions echoing in her heart. (page 11)

The word pertanyaan $(\mathrm{N})$ has a root word tanya $(\mathrm{N})$ with confix per-...-an. The component meaning of confix per-...-an in refers to the base or topic itself. The meaning of pertanyaan is an inquiry of statement. It was translated into questions $(\mathrm{N})$. The meaning of the question is a sentence worded or expressed to elicit 
information. This is the inflectional process as a plural noun because the word is attached with morpheme $-s$. The used translation procedure is transposition because the singular noun in SL turned plural in TL (Newmark, 1988).

\section{Data 3}

SL: Perasaan lega dan segar yang diperolehnya tiap kali habis berlibur di sana tak bisa diukur dengan uang. (page 26)

TL: The feeling of being carefree and revitalized whenever he visited could not be measured in money. (page 16)

The word perasaan $(\mathrm{N})$ has a root word rasa $(\mathrm{N})$ with confix per-...-an. The component meaning of confix per-...-an in refers to the base or topic itself. The meaning of perasaan is a feel or inner state when dealing with something. It was translated into feeling $(\mathrm{N})$ from word root feel $(\mathrm{V})$. The meaning of feeling is an emotional state or reaction. This is a part of the inflectional process as a progressive participle verb with morpheme -ing. This is a transposition translation procedure. The word perasaanbecomes gerund feeling because the different in grammatical structure (Newmark, 1988).

\section{Data 4}

SL: Ini ratusan tahun yang lalu sebelum hutan dirusak untuk perkebunan pala. (page 54)

TL: This was hundred years ago, before the forest was torn down to make way for nutmeg plantation. (page 25)

The word perkebunan $(\mathrm{N})$ has a root kebun $(\mathrm{N})$ with confix per-...-an. The component meaning of confix per-...-an in refers to the base or topic itself. The meaning of perkebunan is a plot of land that is made into a garden. It was translated into plantation $(\mathrm{N})$. The meaning of plantation is an estate on which crops are grown.This is a derivational process because of the attachment of affixes. The word comes from word plant $(\mathrm{N})$ with the suffix $-(a(t))$ ion means activity or result of $\mathrm{X}$. The used translation procedure is transposition because the word perkebunan pala is modifier-modified in ST but changes into nutmeg plantation which is a modifiedmodifier (Newmark, 1988).

\section{Conclusion}

There are some points to be concluded that in translating words with confix into English. The result showed the possibility of translating Indonesian words with attached confixes into English by using the inflectional process or derivational process.

In inflectional, Indonesia's singular noun could turn into a plural noun with morpheme $-s$. There was also a shift with an inflectional verb with be $+-e d$ (passive participle) and morpheme -ing (progressive participle). In adjective form, the inflectional form remained in base form without any morpheme attachment. Derivational morpheme was also discovered in the translation. Some words with the attached confix had affix after being translated.

The most used translation procedure is transposition because there were many shifts at the grammatical level. The word class between Indonesian to English changed during translation. The inflectional process also had a role in transposition 
translation procedure. The t singular noun in SL transformed into plural in TL. The other shift happened because the modifier word and modified word structure are different between the two languages.

The literal translation was the second most used translation procedure because a sentence can be translated directly and be reversed. Modulation is another translation procedure used in the translation. Because of the paraphrasing between words the point of view of the sentence changed.

\section{References}

BadanPengembangan Bahasa danPerbukuan, KementrianPendidikandanKebudayaanRepublik Indonesia. 2016. KamusBesar Bahasa Indonesia. (series online). Available from: https://kbbi.kemdikbud.go.id/ (Accessed June 13th, 2020)

Bassnet, S. 2002. Translation Studies. London and New York, Routledge.

Carstairs, A. and McCarthy. 2002. An Introduction to English Morphology: Word and Their Structure. Edinburgh, Edinburgh University Press Ltd.

Chaer, A. 2008. Morfologi Bahasa Indonesia Pendekatan Proses. RinekaCipta, Jakarta.

Ilyas, N. 2014. A BIG List of Prefixes and Suffixes and Their Meaning. (series online). Available from: https://www.myenglishteacher.eu/blog/prefixes-suffixes-list/ (Accessed June 13th, 2020)

Joseph. 2014. Intro to Translation Studies: Vinay and Darbelnet's Translation Procedures(series online). Available from: http://www.thelinguafile.com/2014/05/intro-to-translation-studiesvinay-and.html (Accessed June 18th, 2020)

Munday, J. 2016. Introducing Translation Study. Routledge 711 Third Avenue, New York, NY.

Newmark, P. 1988. A Textbook of Translation. London and New York: Prentice Hall International (UK) Ltd,p. 84.

Nida, E. A. 1982. The Theory and Practice of Translation. Netherland, The United Bible Societies.

Oxford University. 2020. Oxford Dictionary of English. United Kingdom, Oxford University Press.

Purnomo, B. 2015. Transposition and Modulation to Translate Tourism Texts from English into Indonesian. Arab World English Journal (pg 219-229).

Putrayasa, I. B. 2008. KajianMorfologiBentukDerivasionaldanInfleksional. PT RefikaAditama, Bandung.

Rambe, H. 2003. Mirahdari Banda. Indonesia, Indonesia Tera.

Utami, N. M. V. 2013. The Indonesian Base and Affixes Verb Forms and Their Translational Equivalence in English with Reference to Edensor (thesis). Denpasar, Udayana University.

Vinay, J.P.\& Darbelnet. J.1995. Comparative Stylistics of French and English: A Methodology for Translation. Amsterdam/Philadelphia: John Benjamins Publishing Company 